\title{
Early China 33-34 2010-2011
}

Obituary

Contributors

\section{ARTICLES}

Representations and Uses of Yue Identity along the Southern Frontier of the Han, ca. 200-111 B.C.E.

ERICA BRINDLEY

“The Altars of the Soil and Grain are Closer than Kin" 社稷戚於親:

The Qi 齊 Model of Intellectual Participation and the Jixia 稷下 Patronage Community

ANDREW MEYER

Gai Lu: A Translation and Commentary on a Yin-Yang Military

Text Excavated from Tomb M247, Zhangjiashan OLIVIA MILBURN

Dong Zhongshu's Chunqiu jueyu Reconsidered: On the Legal Interest in Subjective States and the Privilege of Hiding Family Members' Crimes as Developments from Earlier Practice

CHARLES SANFT

Using Sequential Relations of Day-Dates to Determine the Temporal Scope of Western Zhou Lunar Phase Terms XU FENGXIAN (translated by David W. Pankenier) 
The Di Zhi 地支 as Lunar Phases and Their Coordination with the Tian Gan 天干 as Ecliptic Asterisms in a China before Anyang JONATHAN M. SMITH

Response to a Critic

\section{REVIEW ARTICLE}

Paleographic, Historical, and Intellectual History Approaches to Warring States Manuscripts Written on Bamboo Slips: A Review Article XING WEN

\section{REVIEW FORUM}

Li Feng, Landscape and Power in Early China: The Crisis and Fall of the Western Zhou, 1045-771 вс:

Discussion by MARIA KHAYUTINA, YURI PINES, KATHERYN M. LINDUFF, CONSTANCE A. COOK, and CHEN ZHI

The Study of Western Zhou History: A Response and a Methodological Explication LI FENG

\section{BIBLIOGRAPHY}

Shigaku Zasshi Summary of Japanese Scholarship for 2009: Shang, Zhou, Spring and Autumn EBINE RYŌSUKE 海老根量介

Shigaku Zasshi Summary of Japanese Scholarship for 2009: Warring States, Qin and Han ōsHIMA SEIJI 大島誠二

Dissertation Abstracts $\quad 345$

Annual Bibliography $\quad 381$

Books Received $\quad 417$ 
in memoriam

Jean Almire Lefeuvre (1912-2010) 
